\title{
THE YIELD CURVE FACTORS AND ECONOMIC SURPRISES IN THE CHILEAN BOND MARKET
}

\author{
LOS FACTORES DE LA ESTRUCTURA DE TASAS Y SORPRESAS \\ ECONOMICAS EN EL MERCADO DE BONOS DE CHILE
}

\section{LUIS CEBALLOS*}

Central Bank of Chile

\begin{abstract}
This paper attempts to review the main factors of the yield curve in Chilean market during the period 2005-2013. Two different approaches are used to compute the main three factors denoted as the level, slope and curvature of the yield curve. Then, the impact of economic surprises and announcements are analyzed. Our results indicate that local surprises and announcements (both local and external) have similar effects on the estimated factors under both approaches, whereas is evidenced an asymmetric impact in the case of external surprises.
\end{abstract}

Keywords: Economic surprises, yield curve, latent factors, factor analysis.

JEL Classification: E43, E44, G15.

\section{Resumen}

Este trabajo intenta revisar los principales factores de la estructura de tasas en el mercado chileno durante el período 2005-2013. Se utilizan dos enfoques para computar los tres principales factores denotados como el nivel, pendiente y curvatura de la estructura de tasas. Luego se analiza el impacto de sorpresas económicas y anuncios. Nuestros resultados indican que sorpresas locales y anuncios (tanto locales como externos) tienen similares

* I would like to thank Rodrigo Alfaro, Miguel Fuentes and Javier Garcia-Cicco for their useful suggestions and comments. E-mail: lceballos@bcentral.cl 
efectos en los factores bajo ambos enfoques, mientras que se evidencia un impacto asimétrico en el caso de sorpresas externas.

Palabras clave: Sorpresas económicas, estructura de tasas, factores latentes, análisis factorial.

Clasificación JEL: E43, E44, G15.

\section{INTRODUCTION}

The term structure of interest rates provides relevant information for both Central Bank (as other economic authorities) and private market agents. In the first case, the information contained in the yield curve allows to the Central Bank monitoring market expectations about future changes in the policy rate, inflation as well economic growth over the medium to long term. In the case of private agents, they use the information contained in market rates to calibrate the yield curve in order to pricing different financial instruments, investment decisions, among others. Therefore, abrupt changes in the shape of the term structure of interest rates might generate a significant impact on portfolios maintained by private agents as well the information implicit on interest rates.

Because the importance of the information contained in interest rates, this article presents the main factors of the yield curve in the Chilean market. The latent factors of the term structure of interest rates captures all information embedded in interest rates at different maturities in a compact and reduced form. These factors correspond to the level, slope and curvature of the yield curve. Then, the effect of economic news and unconventional monetary policies announcements are analyzed in order to quantifying the impact of such events in the shape of the yield curve.

The contributions of this work are twofold. First, the yield curve factors in Chilean government bond are computed using two different methodologies which have not been applied for Chilean market at high frequency, the Nelson-Siegel model and the principal components analysis (PCA) approach. The PCA is a non-parametric and statistical approach used to compute the main factor in a dataset, reducing its dimension in a few factors each one independent from another. Unlike PCA, the Nelson-Siegel framework corresponds to a parametric model which imposes structure on the factor loadings leading to a highly precise estimation of the factors. However, because both approaches allow us to identify the factor of the yield curve interpreted as level, slope and curvature, a comparison of the results of each approach are made.

The second contribution is to evaluate and quantifying the impact of economic surprises on the factors of the yield curve taking into consideration the asymmetric effect that might exist. Most of empirical works have attempted to evaluate the effect of economic news directly in observed interest rates lacking to an evaluation of the impact to the whole yield curve. Therefore, evaluating the impact on factors instead the interest rates leads to a better comprehension of how the shape of the yield curve 
is affected when economic news or announcements are made and not just in some points of the term structure.

The article is organized as follows. Section 2 presents a brief review of the literature both international and locally regarding the computation of latent factors as well the impact of economic news in the yield curve. Section 3 presents the data used in this article and the main stylized facts. Section 4 presents the methodologies used to compute the factors of the yield curve. Section 5 presents the results of the effects of economic surprises in high frequency and the asymmetric effects evidenced. Finally the Section 6 concludes.

\section{LITERATURE REVISION}

The relationship between the yield curve and macroeconomic variables has generated several lines of study. Among the main international empirical researches are models under the premise of no arbitrage. For example, Dai and Singleton (2000) reported the unobserved factors that explain the yield curve. In same line, Ang and Piazzesi (2003), Hördahl et al. (2002) and Wu (2002) incorporate macroeconomic determinants in structure models of interest rates, which attempt to capture the dynamics of these factors and macroeconomic variables. Diebold and $\mathrm{Li}$ (2006) present a dynamic version of the Nelson-Siegel model (1987) which is able to capture the jointly dynamics of the factors of the yield curve with some macroeconomic variables, being these factors associated with the level, slope and curvature of the yield curve. Another line of research is regards of how interest rates are affected to economic "releases" such as inflation, monetary policy rate (MPR), economic growth, among others. The latter is reported by Gürkaynak et al. (2005), who reported long term effects on forward rates to surprises in macroeconomic variables and monetary policy.

On the other hand, there is a line of research characterized by the use of factor analysis, which corresponds to a nonparametric method for estimating the factors of interest rate structure. Litterman and Scheinkman (1991) and Bliss (1997) used this method to identify the factors that explain the dynamics of the yield curve, identifying that three factors, described as level, slope and curvature, explains in compact form the whole structure of interest rates and found that these factors are similar in terms of the information contained in the factors of Nelson-Siegel model specification. These factors are able to explain $97 \%$ of the variance of interest rates. Furthermore, similar results are reported by Cortázar and Schwartz (1994), who used the methodology of principal components in the commodities market.

In the case of Chilean government bond market, the effects of macroeconomic and monetary policy surprises in the yield curve has been reported by Meyer (2006) who analyzed the response of bond interest rates to economic releases and Larraín (2007) who reported the effects of MPR surprises on bond rates for different maturities. Ochoa (2006) estimates the factors of yield curve using a no-arbitrage model, concluding that these factors correspond to the instantaneous rate and central tendency. Morales (2010) estimates the model proposed by Diebold and Li (2006) for monthly real rates in Chile and reported the dynamics of some macroeconomic variables and 
yield curve factors using a Kalman filter and two-step approach. Finally, Alfaro et al. (2011) estimates a discrete version of the dynamic Nelson-Siegel model, reporting the jointly dynamics between yield curve factors and macroeconomic variables in monthly nominal interest rates. More recently, Chaumont and García-Cicco (2012), using a heteroscedastic approach characterize the effects of monetary policy shocks in financial assets. Nevertheless, the estimation of yield factor using factor analysis and the effect of surprises and unconventional announcements at higher frequency has not been reported in the case of Chile.

\section{DATA}

Data on interest rates in Chilean benchmark government bonds have been obtained from Central Bank of Chile's website. The interest rates are in daily frequency and correspond to nominal government bond (denoted as BCP) for maturities longer than one year, and interest rates swaps for maturities shorter than one year. The maturities considered correspond to 3,6 and 12 months for interest rate swaps as well as 2, 5 and 10 years in BCP instruments. The sample period is January 2005 to April 2013. In Table 1a is reported the main statistics of the yield curve of interest rates, which shows that although the structure of average rates in the 2005-2013 samples was increasing, it can take different forms over time. This is key feature when using any particular model to calibrate the yield curve; must have the flexibility to capture different shapes of the yield curve over time. Another important feature of the yield curve is the fact that shorter maturity rates are more volatile than long term rates, which have the highest level of persistence. Moreover, the correlation between interest rates at different maturities is high, except in the longest term (the 10 year interest rate), which presents the lower correlation with interest rates shorter than one year (see Table 1b).

The structure of nominal rates in Chile has registered episodes of substantial volatility and abrupt changes in the level of interest rates for different maturities. In

TABLE 1A

DESCRIPTIVE STATISTICS

\begin{tabular}{|c|c|c|c|c|c|}
\hline Maturity & Mean & Median & Max & Min & Standar dev. \\
\hline $3 \mathrm{~m}$ & 4.32 & 4.94 & 8.62 & 0.44 & 1.95 \\
$6 \mathrm{~m}$ & 4.43 & 4.94 & 8.78 & 0.54 & 1.88 \\
$1 \mathrm{y}$ & 4.88 & 5.25 & 8.85 & 0.42 & 1.57 \\
$2 \mathrm{y}$ & 5.25 & 5.39 & 8.79 & 1.67 & 1.22 \\
$5 \mathrm{y}$ & 5.80 & 5.68 & 8.55 & 3.66 & 0.72 \\
$10 \mathrm{y}$ & 6.08 & 6.15 & 8.21 & 4.36 & 0.59 \\
\hline
\end{tabular}

Source: Author's calculations. 


\section{TABLE 1B}

\section{CORRELATION MATRIX}

\begin{tabular}{|l|c|c|c|c|c|c|}
\cline { 2 - 7 } \multicolumn{1}{c|}{} & $3 \mathrm{~m}$ & $6 \mathrm{~m}$ & $1 \mathrm{y}$ & $2 \mathrm{y}$ & $5 \mathrm{y}$ & $10 \mathrm{y}$ \\
\hline $3 \mathrm{~m}$ & 1.00 & & & & & \\
$6 \mathrm{~m}$ & 0.99 & 1.00 & & & & \\
$1 \mathrm{y}$ & 0.95 & 0.98 & 1.00 & & & \\
$2 \mathrm{y}$ & 0.90 & 0.94 & 0.99 & 1.00 & & \\
$5 \mathrm{y}$ & 0.64 & 0.70 & 0.79 & 0.88 & 1.00 & \\
$10 \mathrm{y}$ & 0.09 & 0.16 & 0.27 & 0.42 & 0.80 & 1.00 \\
\hline
\end{tabular}

Source: Author's calculations.

particular, during the financial crisis in 2008 period, significant declines in rates were recorded at all maturities, highlighting the decrease for about 400 basis points in the 10 -year bond rate, and also was evidenced an increase in the slope of the yield curve (defined as the difference between the long rate and short rate) to levels not seen until then as shown in Figure 1.

\section{FIGURE 1}

NOMINAL INTEREST RATES

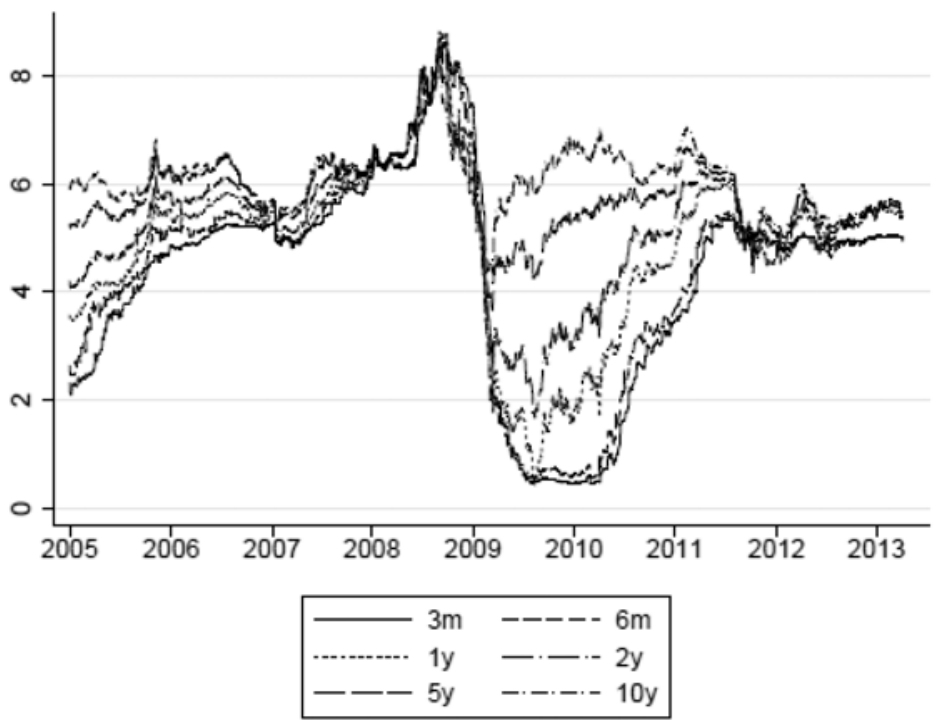

Source: Central Bank of Chile. 


\section{YIELD CURVE FACTORS ESTIMATION}

Two methodologies are described in this section to estimate the yield curve factors: (i) the Nelson-Siegel model and (ii) the principal components (PCA) methodology described by Bliss (1997).

\subsection{Nelson-Siegel Model Approach}

Both market players and policymakers use the information contained in the yield curve to extract expectations about future movements on MPR or inflation expectations, or to have a curve that allows them to be used as a reference for the valuation of other financial instruments. As noted in the previous section, the model must have the flexibility to capture the different shapes of the yield curve at a particular day (e.g. curve with positive or negative slope). According to BIS (2005), the model of Nelson-Siegel (1987) is one of the most used by different Central Banks for calibration of the structure of interest rates due to its easy computation and good fit to observed interest market rates. This model can be written as:

$$
y_{t}^{\tau}=\beta_{0, t}+\beta_{1, t}[(1-\exp (-\lambda \tau)) / \lambda \tau]+\beta_{2, t}[(1-\exp (-\lambda \tau)) / \lambda \tau-\exp (-\lambda \tau)]
$$

where $y^{\tau}$ corresponds to the interest rate observed at maturity $\tau$ in time $t$. The model (1) calibrated parameters $\left\{\beta_{0}, \beta_{1}, \beta_{2}, \lambda\right\}$, such that the error between the observed rates and the rates obtained from the model is minimized. The interpretation of parameters in (1) is given by the impact that they have on interest rates for different maturities as shown in Figure 2. Thus, the parameter $\beta_{0}$ is related as the level factor $(\mathrm{L})$ as it has permanent effects on the level of yield curve. The parameter $\beta_{1}$ is the slope factor (S) given its effect mainly on the short end of the curve. Finally, the parameter $\beta_{2}$ is associated with curvature $(\mathrm{C})$ since the greatest impact on rates in intermediate maturities. Meanwhile, the parameter $\lambda$ corresponds to the decay rate of the yield curve at longer maturities.

The estimation of the model is not linear and cross section. In the first case, the parameter $\lambda$ imposes to the model the nonlinearity feature. In the second case, the model (in the original specification presented by Nelson-Siegel) ignores the dynamics of time series of interest rates, so merely calibration rates in cross section is needed. In addition, the NS model has significant constraints on rates to levels which converge:

- At time $0(\tau \rightarrow 0)$, the estimated interest rate converges to $\beta_{0}+\beta_{1}$ (which is associated with the monetary policy rate).

- At long term $(\tau \rightarrow \infty)$, the estimated interest rate converges to $\beta_{0}$ (which is denoted as the long-term rate of the economy).

In order to obtain the factors of (1), we proceed to fix the $\lambda$ parameter of the model for two reasons: (1) When this parameter is fixed, the model is linear and can be estimated by OLS easily, and (2) changes in the parameters (factors) estimates of 


\section{FIGURE 2}

FACTOR LOADINGS

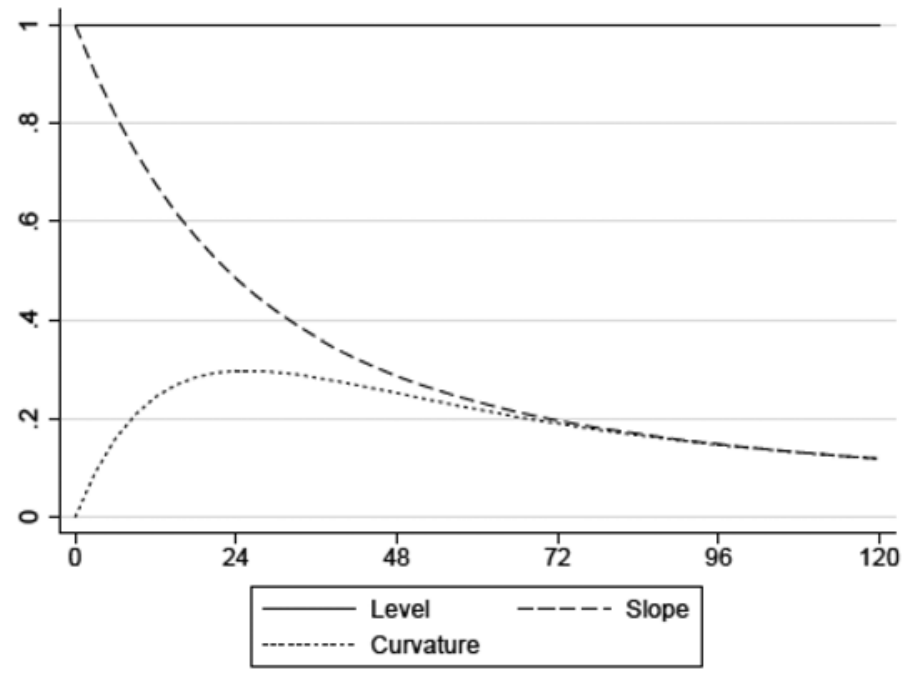

Source: Author's calculations.

the model can be interpreted as actual changes in the level, slope and curvature of the yield curve (and not associated to changes in $\lambda$ parameter). With this we proceed to select the value of $\lambda$ that minimizes the root mean square error (RMSE) of adjustment to market rates observed in daily rate during the sample period. The Figure 3 shows the RMSE shows set in considering a grid of values for $\lambda$ parameter, which shows that taking $\lambda=0.11$ the error is minimized ${ }^{1}$.

The calibration of $\lambda$ is in line with previous studies reported for Chilean market. Herrera and Magendzo (1997) reported that $\lambda$ is between 0.069 and 0.133 in the sample March to June 1996. Meanwhile, Morales (2010) based on real interest rates (denoted as BCUs) in the period from April 1996 to July 2001 found similar results to previous study. More recently, it is reported by Alfaro et al. (2011), who using BCP nominal bond rates from July 2004 to June 2011, calibrated $\lambda$ parameter based on a set of criteria such as RMSE, adjusted R2, AIC and BIC concluding that $\lambda$ is ranges from 0.083 to 0.127 .

Finally, we proceed to estimate by OLS the model (1) for each day in the period January 2005 to April 2013. This method ignores the time series dynamics of the

1 An alternative exercise to estimate the nonlinear model for the entire sample was also performed, which showed that the average value for $\lambda$ parameter was similar to the two-step approach used in this paper. 
FIGURE 3

RECM AT DIFFERENT VALUES OF $\lambda$

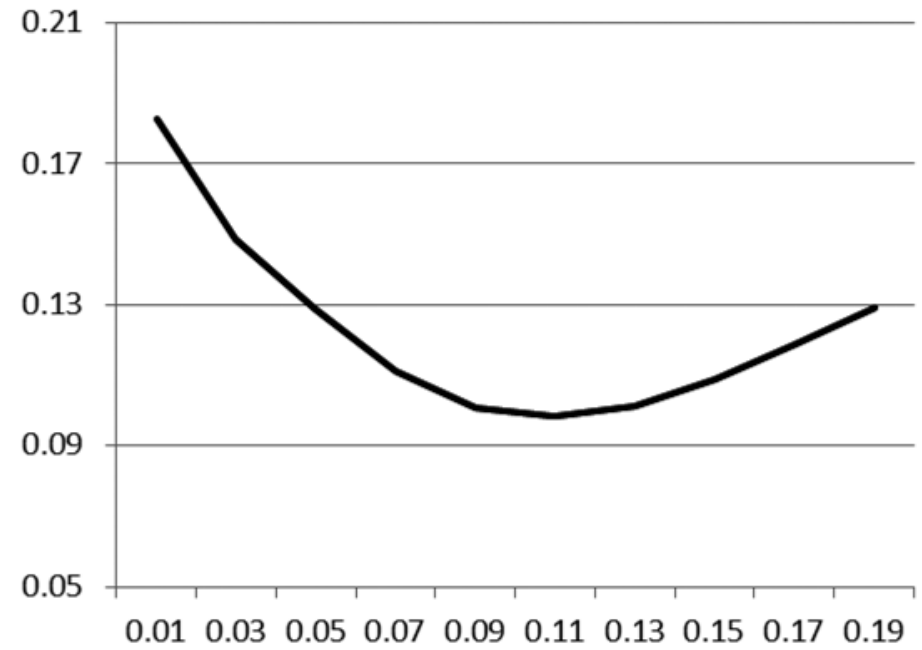

Source: Author's calculations.

factors, and corresponds to the two-step approach, in which it is possible to estimate separately the parameters of the model and then estimate its dynamics ${ }^{2}$. On the other hand, there is the dynamic version of the Nelson Siegel model proposed by Diebold and $\mathrm{Li}$ (2006) in which the estimation of model (1) and the dynamics of time series by a factor VAR, are calibrated jointly using a Kalman filter. However, as Morales (2010) reports, in the case of the yield curve in Chilean market, the estimated factors using the two-step approach or dynamic version produce similar results. With this, the present work uses the cross-sectional approach.

The factors estimated under this approach ar shown in Figure 4. It is appreciated that the level factor is persistent and is attributable to the model derived from Nelson-Siegel, in which this component represents the long-term interest rate. The slope factor seems to be much more volatile as well as curvature factor, particularly during the period 2009-2010. This period was characterized by the implementation of unconventional monetary policy (known as FLAP in Chilean case), which attempted to set the monetary policy rate at lowest levels for a long period.

2 See Alfaro et al. (2011) and Morales (2010) who report the dynamic structure factors of nominal and real rates respectively in the case of Chile. 
FIGURE 4

FACTORS ESTIMATION UNDER NS MODEL

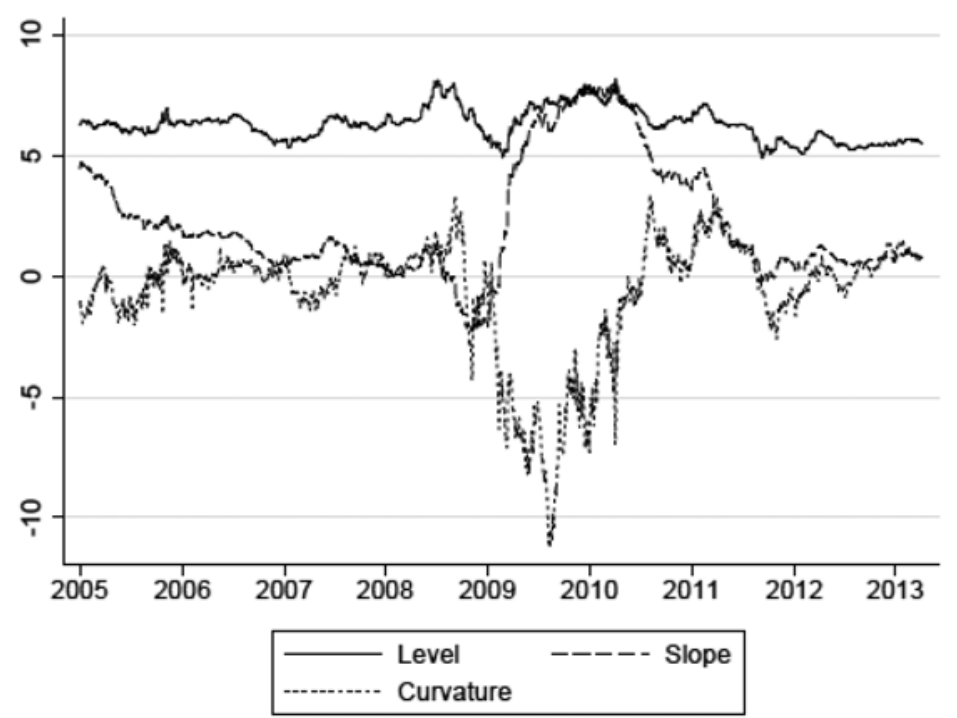

Source: Author's calculations.

\subsection{Principal Component Analysis (PCA) approach}

The method of principal components analysis (PCA) seeks to maximize the variance of the data based on a set of factors of smaller dimension than the original data. Let $X$ denotes the data matrix (in this case interest rates) such that $X=\left[x_{1}, \ldots, x_{N}\right]^{T}$ , where each $x$ vector is of dimension $k$ (in this case, the total rates observed at each instant $k=6$ ). The method of principal components (PC) find a matrix $P=\left[p_{1}, \ldots, p_{d}\right]^{T}$ that maps each observation of $X$ in a space with dimension less than the original data set $(d \leq k)$. Each vector $p$ maximizes the variance of $X$ in orthogonal directions with respect to the remainder, such that the amount of variance explained by each vector decreases from $p_{1}$ to $p_{d}$. To illustrate, in the particular case of finding the first principal component we have:

$$
C=\frac{1}{N} \sum_{j=1}^{N}\left(x_{j}-\mu\right)\left(x_{j}-\mu\right)^{T}
$$


where $C$ denotes de variance covariance matrix of $X$, and $\mu=\frac{1}{N} \sum_{j=1}^{N} x_{j}$ corresponds to the mean of each vector $x$. Then, the projected variance $p_{1}$ corresponds to:

$$
v=\frac{1}{N} \sum_{j=1}^{N}\left(p_{1}^{T} x_{j}-p_{1}^{T} \mu\right)^{2}=p_{1}^{T} C p_{1}
$$

The method seeks to find $p_{1}$ as to maximize $\mathrm{v}$ subject to the constraint that $p_{1}$ is a unit vector. The solution to the above is:

$$
C p_{1}=\lambda_{1} p_{1}
$$

where (2) corresponds to the decomposition of the matrix $C$ in the eigenvalue $p_{y}$ eigenvector $\lambda$. In general, the matrix $C$ can be decomposed as:

$$
C=P \Lambda P^{T}
$$

which is a diagonal matrix with $\left\{\lambda_{1}, \lambda_{2}, \ldots, \lambda_{d}\right\}$ elements being $\lambda_{1} \geq \lambda_{2} \geq \ldots \geq \lambda_{d}$. Furthermore, each column of $P$ corresponds to the principal component of $X$ matrix data.

Factors estimated by this method are obtained by rotation of the loadings matrix (or weights) for the purpose of minimizing the variance of the first factor loadings, as reported by Bliss (1997). Factors estimated under this methodology are presented in Figure 5.

\section{FIGURE 5}

FACTORS ESTIMATION UNDER PCA APPROACH



Source: Author's calculations. 
The economic interpretation of each factor is given by the loadings or weights of each factor relative to interest rates at different maturities as shown in Figure 6. Since results are dependent on the sample used, the loadings obtained in two different samples are presented (the first sample seen prior to the financial crisis of 2008 and the second sample considering the full 2005-2013 sample). In both samples, the results are similar.

FIGURE 6

FACTOR LOADINGS

(a) $2005-2008$

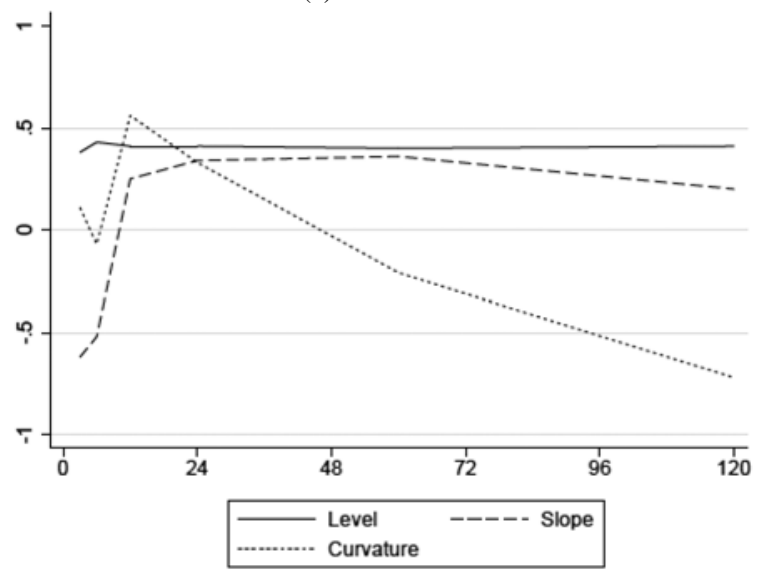

(b) $2005-2013$

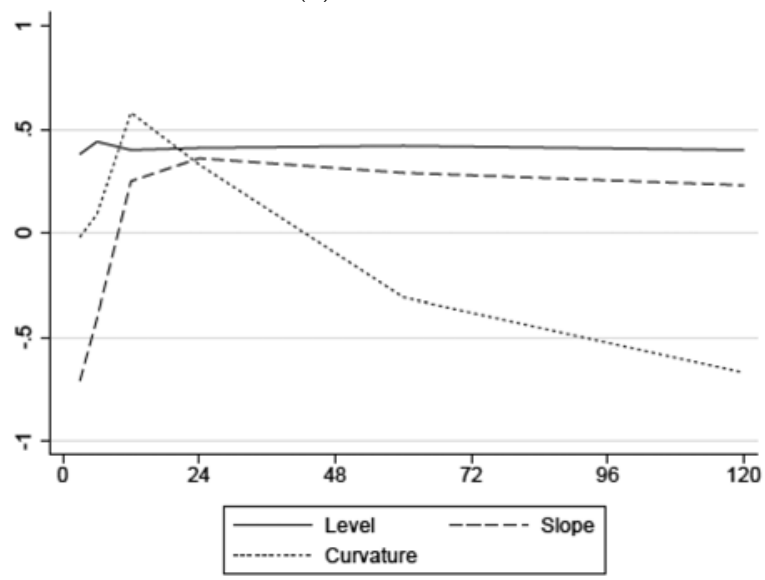

Source: Author's calculations. 
Regarding the factors obtained, the first factor, denoted as the level of the yield curve contains loadings around 0.4 for all maturities of interest rates, meaning that a change in that factor has similar effects in all interest rates. The second factor, denoted as the slope of the yield curve is due the negative loadings in interest rates with maturities shorter than a year and longer positive. This implies that changes in this factor, produces changes in the short and long end of the curve in opposite directions, affecting the slope of the yield curve. Finally, the third factor is denoted as curvature since changes in this factor has positive effects on the middle part of the curve, and negative at the long end, thereby affecting the curvature of the yield curve.

Table 2 reports the total variance of the interest rates explained by each factor estimated. For robustness consideration, different samples are considered achieving similar results. The first subsample, spanning March 2005 to September 2008, was characterized by historical increase in the risk indicators, episodes of turbulence in financial markets and significant slowdown in production. The second subsample, spanning August 2009 to December 2013, was characterized by decreases in the risk levels as well as a gradual recovery of output growth. Also during this period the first types of unconventional monetary policies aimed to normalize the functioning of financial markets and stimulate the economy began being implemented. Thus, both subsamples takes into consideration the financial distress faced by the economy, and therefore its impact on interest rates. The results show, as same as reported by Bliss (1997) in the case of the yield curve for US, that the first factor explains about $93 \%$ of the variance, while the three factors explain jointly about $99 \%$ of total variance. Meanwhile, Litterman and Scheinkman (1991) reported the same pattern in Treasury rates, the first factor explains the largest variance of the data (90\%), and the first three factors $98 \%$ overall. This has also been evidenced in the copper futures market (see Cortázar and Schwartz (1994)). In all cases, the first factor is referred to the level, the second factor to the slope, and the third factor of the curvature.

\section{TABLE 2}

TOTAL VARIANCE EXPLAINS FOR EACH FACTOR $(*)$

\begin{tabular}{|c|c|c|c|c|}
\hline Sample & Level & Slope & Curvature & Total \\
\hline A & 93.31 & 4.31 & 1.57 & 99.19 \\
B & 92.02 & 5.42 & 1.81 & 99.24 \\
\hline Total & 93.78 & 4.38 & 1.05 & 99.20 \\
\hline
\end{tabular}

(*) Sample A considers the period between 01/03/2005 and 09/15/2008. Sample B considers the period between 09/16/2008 and 04/03/2013. Sample Total considers the period between 01/03/2005 and 04/03/2013. 


\subsection{Factor comparison}

The level factor $(L)$ under the $N S$ model approach, corresponds to the long rate of the economy (denoted by $\beta_{0}$ ), whereas in the $P C A$ approach corresponds to a combination of all interest rates. Because of that, it is expected that the factor obtained by NS might be less volatile to changes in market rates, as this is mainly due to changes in the long rate of the economy (e.g. the 10-year bond rate, which is the less volatile rates under study as was reported in Section 2). Furthermore, the factor obtained by PCA responds to changes in interest rates at different maturities, being more volatile by construction. However, the correlation between the two factors is 0.46 for the full sample ${ }^{3}$.

Meanwhile, the slope factor $(\mathrm{S})$ and curvature $(\mathrm{C})$, have a high correlation in NS and PCA approaches, being 0.97 and 0.87 respectively ${ }^{4}$. However, under the PCA approach, these factors contribute less to explain the interest rates than NS approach.

Finally, even when these factors derived under both approaches are not directly comparable, we proceed in the next section to compare the effect of surprises and announcements in each factor under both methods, as they allow representing the information of the yield curve in three factors.

\section{QUANTIFYING THE IMPACT OF ECONOMIC NEWS AND ANNOUNCEMENTS}

This section presents a review of macroeconomic surprises taken in consideration as well announcements unconventional monetary policies and exchange rate intervention made by the Central Bank. Then we proceed to describe the construction of macroeconomic surprises and the effects they have on the factors of the yield curve presented in previous section at high (daily) frequency, and the asymmetric effects evidenced.

\subsection{Economic surprises and announcements}

The macroeconomic variables used correspond to those commonly reported in the literature, which are the monthly activity index (IMACEC), the inflation rate (CPI), the monetary policy rate (MPR) and unemployment for Chilean economy. Same variables are considered in the case of U.S. With these eight variables mentioned above, we proceed to compute the macroeconomic surprises which are defined as follows:

3 This corresponds to the daily correlation of the estimated factors. When considering the period before the financial crisis (January 2005 to August 2008), the correlation increases to 0.61 .

4 In the case of the slope factor, the correlation is performed between the PCA factor and the negative factor under the NS approach $\left(-\beta_{1}\right)$. 


$$
S_{t}^{j}=X_{t}^{j}-E\left(X_{t}^{j}\right)
$$

where $S_{t}^{j}$ corresponds to the surprise of the macroeconomic variable $j$ at time $t$. This surprise measure is constructed as the difference between actual $X_{t}^{j}$ and expected data $E\left(X_{t}^{j}\right)$ which corresponds to the value reported by Bloomberg regarding the median estimation of agents and financial institutions in the market. It is important to note that all effective measures correspond to the first release of the series, and in no case revisions or corrected data are considered. Also is considered both local and external announcements of monetary policy and other such as announcements of unconventional measures of monetary policy and foreign exchange intervention. Dates and description of these are listed in detail in Table 3.

Releases of local variables such as inflation, MPR and activity (production) are reported in the first half of every month, whereas unemployment releases are informed the last day of each month. On the other hand, external releases regards unemployment is reported the first days of each month, while the rest of the macroeconomic news such as inflation and activity are reported at mid-month. Meanwhile, Fed Fund announcements have been reported mainly during the third and fourth week. In the case of exchange rate intervention announcements, the dates considered are both when intervention announcement was made and sterilization program was informed by the Central Banks. While the intervention in 2008, the detailed program of sterilization was reported nearly a month after the intervention announcement, in the intervention of 2011 the sterilization program was announced a day after the announcement of reserve accumulation program.

\section{TABLE 3}

\section{UNCONVENTIONAL MP AND INTERVENTION ANNOUNCEMENTS}

\begin{tabular}{|c|c|c|}
\hline Type & Date & Description of announcement \\
\hline Flap & 07-09-2009 & $\begin{array}{r}\text { Provides liquidity to banks at } 3 \text { and } 6 \text { months of the current } \\
\text { MPR. Suspends debt issuance } 1 \text { and } 2 \text { years. }\end{array}$ \\
\hline Int 2008 & $\begin{array}{l}04-10-2008 \\
05-07-2008\end{array}$ & $\begin{array}{r}\text { Announcement of reserves program for } \$ 8,000 \mathrm{MM} \\
\text { Sterilization of reserve accumulation }\end{array}$ \\
\hline Int 2011 & $\begin{array}{l}01-03-2011 \\
01-04-2011\end{array}$ & $\begin{array}{r}\text { Announcement of reserves program for } \$ 12,000 \mathrm{MM} \\
\text { Sterilization of reserve accumulation }\end{array}$ \\
\hline QE1 & $11-25-2008$ & Purchase U.S. \$ 600 billion in MBS \\
\hline QE2 & $11-03-2010$ & Purchase U.S. $\$ 600$ billion in bonds for long duration \\
\hline QE3 & 09-13-2012 & Purchase $\$ 40$ billion in MBS \\
\hline Twist & 09-21-2011 & $\begin{array}{l}\text { Purchase U.S. } \$ 400 \text { billion in bonds with duration between } 6 \\
\text { and } 30 \text { years, and selling bonds with less than three years duration. }\end{array}$ \\
\hline Extension & $12-12-2012$ & Purchase $\$ 40$ billion in MBS and $\$ 45$ billion in long duration bonds \\
\hline
\end{tabular}




\subsection{Modeling the impact of surprises and announcements}

We proceed to test the following specification in order to quantify the impact of local and external macroeconomic surprises, as well as announcements over the yield curve factors obtained by (1) and (3):

$$
\Delta F_{t}^{k}=\alpha+\beta \Delta F_{t-1}^{k}+\sum_{i=1}^{N} \delta_{i} S_{i}+\sum_{j=1}^{M} \eta_{j} D_{j}+\varepsilon_{t}
$$

where $F_{t}^{k}$ is the vector of estimated factors by focusing $k$ (Nelson-Siegel or PCA) on day $t, S_{i}$ corresponds to the macroeconomic surprises explained in (4), and $D_{j}$ correspond to dummies for intervention announcements or unconventional monetary policy. Both in the case of the rate of local and foreign monetary policy, as well as announcements of policy and interventions, it is considered that the effect on interest rates market is captured by the next working day because the local market is currently closed at the time of publication.

In order to ensure that the impact of macroeconomic variables is well measured, was take in consideration the asymmetric impact of macroeconomic surprises in (5) distinguishing positive from negative surprises. Test of non-normality of the series, which shows that we cannot reject the non-normality of some macroeconomic surprises using different test is reported in Table 4.

\section{TABLE 4}

NON-NORMALITY TEST: P-VALUES $(*)$

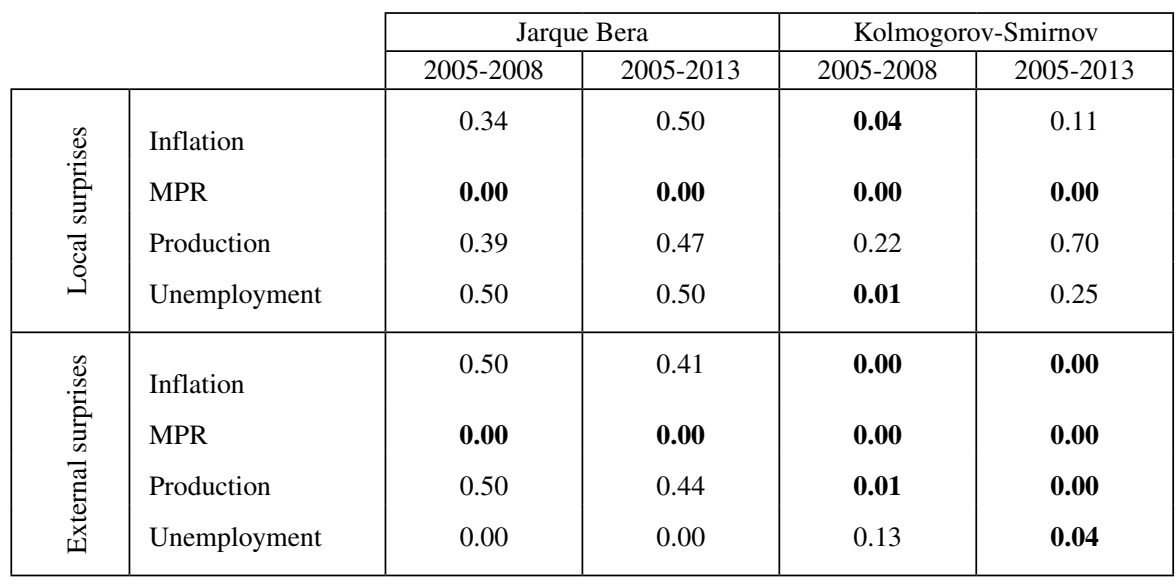

(*) The values in bold i ndicate rejection of hypothesis of normality in the variable specified. 
Table 5 reports the results of the estimation (5) approaches using NS and PCA. For each method of obtaining factors, the effect of a total surprise, that is, no difference the sign of the surprise, as also results from the asymmetry of each shock reports reported. For both local and external intervention ads surprises, the coefficients are multiplied by 100 .

Table 5a contains the effects of macroeconomic surprises on the factor "level". Regarding local surprises, it is appreciated that both approaches reports similar results. Both MPR and inflation surprises have positive coefficient, indicating that surprises in MPR or inflation above market expectations, generates an increase in level of yield curve. Meanwhile, under the PCA approach, unemployment surprises are significant. Moreover, it is seen that the effect of unemployment surprises registers an asymmetric effect on the factor level. On the other hand, external surprises have asymmetric effects in both methodologies. In the case of NS approach, positive surprises of MPR and unemployment are significant, while under PCA, inflation, activity and MPR surprises are significant. Finally, the effects of local announcements of interventions are significant in both approaches, while the announcement of the unconventional monetary policy (FLAP) is significant under PCA. The effect of the FLAP can be explained based on the economic interpretation of each factor in both methodologies, while in the case of NS this factor is represented by the long-term rate of the economy, the PCA approach this factor represents a weighting of all interest rates (both short and long), which may suggest that effects of local advertising has no effect on the long-term rate of the economy, but at shorter maturities does. Finally, external announcements of unconventional monetary policy are all significant, being announcements of Twist operation and QE1 generating the highest incidence in such factor.

Table $5 \mathrm{~b}$ reports the effects of surprises on the slope factor of the yield curve. Both local and external surprises are significant only in MPR case. The economic impact of this surprise is a reduction in the slope of the yield curve. In both cases an asymmetric effect of the surprise in slope factor is not evidenced. For external announcements similar results are reported, being significant surprises on MPR but in opposite sign. On the other hand, the announcements of interventions are significant and positive, while FLAP registers a negative effect under both approaches. Meanwhile, external unconventional announcements are significant in both approaches (except in QE3).

Finally, the Table $5 \mathrm{c}$ reports the impact of surprises on the curvature factor. Local MPR surprises are relevant under NS whereas external MPR surprises reports an asymmetric effect, being relevant the positive surprises in both approaches. Regarding local announcements, the FLAP generates lesser curvature in the yield curve, while the announcement of intervention of 2011 are positive under NS, while the opposite sign under the PCA approach is reported. Finally, an external surprise shows mixed results. Based on NS, announcements for QE1, QE2 and Operation Twist are significant, while based on PCA all significant announcements are reported in that factor. 


\section{TABLE 5A}

IMPACT OF SURPRISES AND ANNOUNCEMENTS ON LEVEL FACTOR $L(*)$

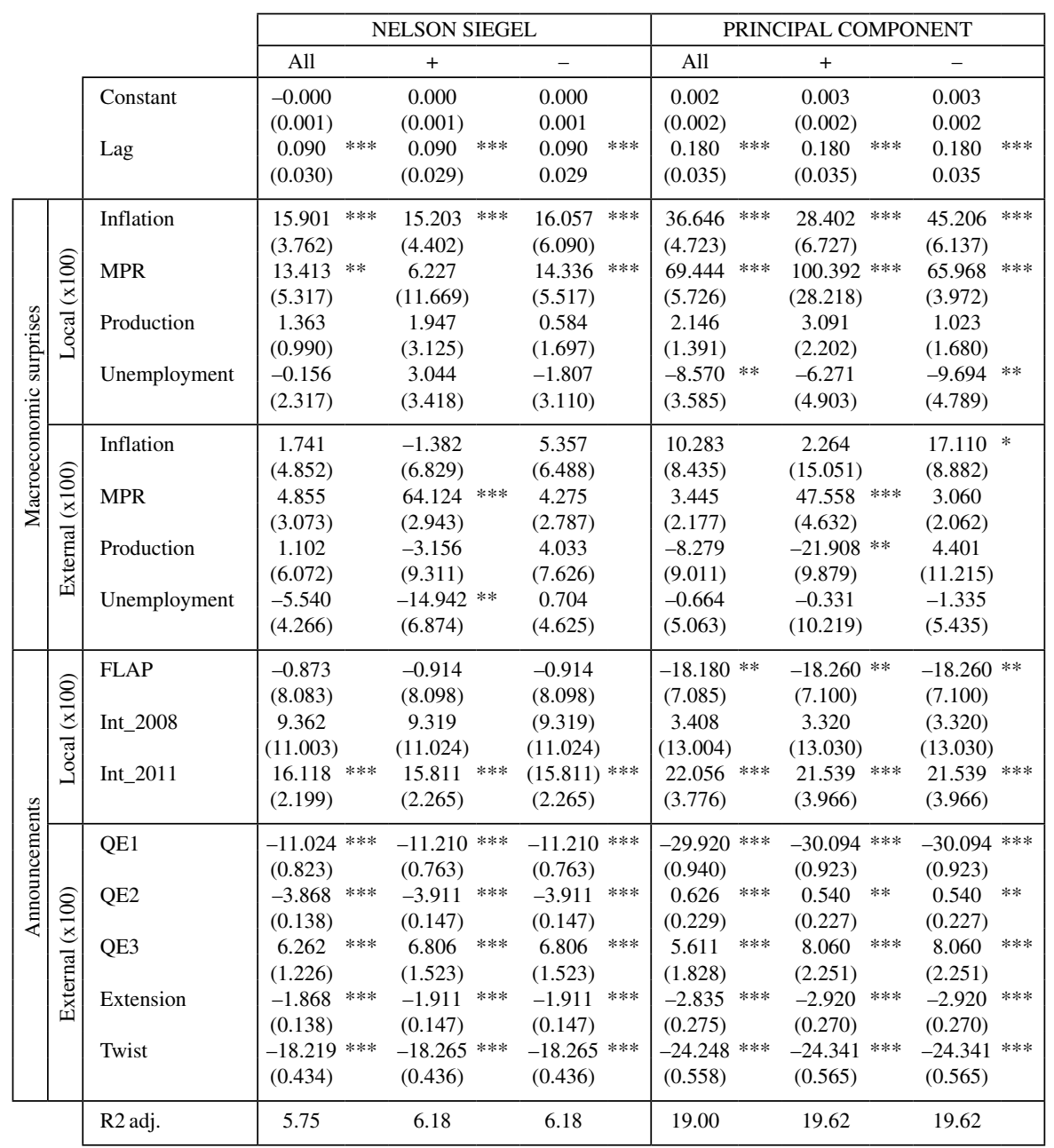

(*) Results are reported based on the Nelson Siegel model and Principal Components approaches. Coefficients of surprises and local and external advertisements multiplied by 100 . All variables expressed in basis points. The Total column shows the effect of each factor in the surprise considering the total macroeconomic surprises. The + column considers the effect of positive surprises in the factors. The - column considers the effect of negative surprises in the factors.

*** Significant at $1 \%$.

$* * \quad$ Significant at $5 \%$.

* $\quad$ Significant at $10 \%$. 


\section{TABLE 5B}

IMPACT OF SURPRISES AND ANNOUNCEMENTS ON SLOPE FACTOR $S(*)$

\begin{tabular}{|c|c|c|c|c|c|c|c|c|c|c|c|c|c|}
\hline & & \multicolumn{5}{|c|}{ NELSON SIEGEL } & \multicolumn{6}{|c|}{ PRINCIPAL COMPONENTS } \\
\hline & & & All & & + & & - & All & & + & & - & \\
\hline & & $\begin{array}{l}\text { Constant } \\
\text { Lag }\end{array}$ & \begin{tabular}{|c|}
-0.003 \\
$(0.002)$ \\
0.033 \\
$(0.049)$
\end{tabular} & & $\begin{array}{c}-0.003 \\
(0.002) \\
0.031 \\
(0.049)\end{array}$ & & $\begin{array}{c}-0.003 \\
0.002 \\
0.031 \\
0.049\end{array}$ & $\begin{array}{c}-0.190 \\
(0.136) \\
-0.276 \\
(4.849)\end{array}$ & & $\begin{array}{l}-0.169 \\
(0.139) \\
-0.393 \\
(4.892)\end{array}$ & & $\begin{array}{c}-0.169 \\
0.139 \\
-0.393 \\
4.892\end{array}$ & \\
\hline \multirow{2}{*}{ 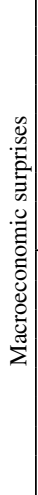 } & 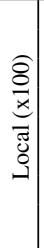 & $\begin{array}{l}\text { Inflation } \\
\text { MPR } \\
\text { Production } \\
\text { Unemployment }\end{array}$ & \begin{tabular}{|c|}
3.969 \\
$(4.346)$ \\
-87.643 \\
$(13.466)$ \\
-0.820 \\
$(1.801)$ \\
-0.852 \\
$(2.948)$
\end{tabular} & *** & $\begin{array}{c}0.344 \\
(4.829) \\
-116.995 \\
(30.540) \\
1.070 \\
(1.731) \\
3.747 \\
(3.865)\end{array}$ & $* * *$ & $\begin{array}{l}7.023 \\
(7.511) \\
-84.102 * * * \\
(14.076) \\
-3.332 \\
(3.463) \\
-3.196 \\
(3.791)\end{array}$ & \begin{tabular}{|c|}
2.221 \\
$(2.743)$ \\
-61.360 \\
$(8.683)$ \\
-0.777 \\
$(1.262)$ \\
-1.388 \\
$(2.315)$
\end{tabular} & $* * *$ & $\begin{array}{c}-1.247 \\
(3.219) \\
-79.090 \\
(20.900) \\
0.533 \\
(1.323) \\
1.940 \\
(3.210)\end{array}$ & $* * *$ & $\begin{array}{c}5.502 \\
(4.723) \\
-59.214 \\
(9.192) \\
-2.501 \\
(2.357) \\
-3.053 \\
(2.933)\end{array}$ & $* * *$ \\
\hline & 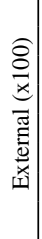 & $\begin{array}{l}\text { Inflation } \\
\text { MPR } \\
\text { Production } \\
\text { Unemployment }\end{array}$ & $\begin{array}{c}-8.789 \\
(4.710) \\
5.318 \\
(2.556) \\
-1.416 \\
(5.988) \\
-5.229 \\
(7.731)\end{array}$ & $\begin{array}{l}* \\
* *\end{array}$ & $\begin{array}{c}-10.800 \\
(7.810) \\
66.247 \\
(3.369) \\
-6.579 \\
(8.887) \\
-14.539 \\
(15.751)\end{array}$ & $* * *$ & $\begin{array}{c}-4.906 \\
(6.824) \\
4.867 \quad * * \\
(2.251) \\
1.013 \\
(7.853) \\
0.983 \\
(6.677)\end{array}$ & $\begin{array}{c}-5.775 \\
(4.143) \\
3.437 \\
(1.960) \\
-2.435 \\
(4.213) \\
-2.031 \\
(5.580)\end{array}$ & $*$ & $\begin{array}{c}-6.885 \\
(6.218) \\
33.055 \\
(2.829) \\
-6.842 \\
(6.635) \\
-5.420 \\
(11.977)\end{array}$ & $* * *$ & $\begin{array}{c}-3.412 \\
(6.159) \\
3.352 \\
(1.973) \\
0.118 \\
(5.487) \\
0.183 \\
(4.734)\end{array}$ & $*$ \\
\hline \multirow[b]{2}{*}{ 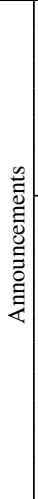 } &  & $\begin{array}{l}\text { FLAP } \\
\text { Int_2008 } \\
\text { Int_2011 }\end{array}$ & $\begin{array}{l}-9.922 \\
(4.628) \\
14.717 \\
(8.149) \\
25.725 \\
(2.044)\end{array}$ & $* * *$ & $\begin{array}{l}-9.973 \\
(4.634) \\
14.684 \\
(8.163) \\
24.859 \\
(2.160)\end{array}$ & $\begin{array}{l}* * \\
* \\
* * * \\
*\end{array}$ & $\begin{array}{l}-9.973 * * \\
(4.634) \\
(14.684) * \\
(8.163) \\
(24.859) * * * \\
(2.160)\end{array}$ & $\begin{array}{c}-10.328 \\
(2.463) \\
9.195 \\
(4.967) \\
9.195 \\
(4.967)\end{array}$ & $\begin{array}{l}* * * \\
* \\
* * *\end{array}$ & $\begin{array}{c}-10.357 \\
(2.466) \\
9.176 \\
(4.974) \\
9.176 \\
(4.974)\end{array}$ & $\begin{array}{l}* * * \\
*\end{array}$ & $\begin{array}{c}-10.357 \\
(2.466) \\
(9.176) \\
(4.974) \\
9.176 \\
(4.974)\end{array}$ & $\begin{array}{l}* * * \\
* \\
* * *\end{array}$ \\
\hline &  & $\begin{array}{l}\text { QE1 } \\
\text { QE2 } \\
\text { QE3 } \\
\text { Extension } \\
\text { Twist }\end{array}$ & $\begin{array}{c}-14.634 \\
(0.764) \\
2.365 \\
(0.188) \\
1.983 \\
(1.199) \\
-1.668 \\
(0.185) \\
-20.800 \\
(0.278)\end{array}$ & $\begin{array}{l} \\
* * * \\
* * *\end{array}$ & $\begin{array}{c}-14.771 \\
(0.739) \\
2.324 \\
(0.184) \\
2.433 \\
(1.562) \\
-1.707 \\
(0.187) \\
-20.832 \\
(0.298)\end{array}$ & $\begin{array}{l}* * * \\
* * * \\
* *\end{array}$ & $\begin{array}{cl}-14.771 & * * * \\
(0.739) & \\
2.324 & * * * \\
(0.184) & \\
2.433 & \\
(1.562) & \\
-1.707 & * * * \\
(0.187) & \\
-20.832 & * * * \\
(0.298) & \end{array}$ & $\begin{array}{c}-11.932 \\
(0.609) \\
4.184 \\
(0.145) \\
0.706 \\
(0.844) \\
-1.810 \\
(0.136) \\
-12.810 \\
(0.136)\end{array}$ & $\begin{array}{l}* * * \\
* * * \\
\\
* * * \\
* * *\end{array}$ & $\begin{array}{c}-11.966 \\
(0.632) \\
4.161 \\
(0.141) \\
1.196 \\
(1.095) \\
-1.832 \\
(0.139) \\
-12.832 \\
(0.139)\end{array}$ & $\begin{array}{l}* * * \\
* * *\end{array}$ & $\begin{array}{c}-11.966 \\
(0.632) \\
4.161 \\
(0.141) \\
1.196 \\
(1.095) \\
-1.832 \\
(0.139) \\
-12.832 \\
(0.139)\end{array}$ & $\begin{array}{l}* * * \\
* * *\end{array}$ \\
\hline & & R2 adj. & 20.20 & & 20.83 & & 20.83 & 18.29 & & 18.76 & & 18.76 & \\
\hline
\end{tabular}

(*) Results are reported based on the Nelson Siegel model and Principal Components approaches. Coefficients of surprises and local and external advertisements multiplied by 100 . All variables expressed in basis points. The Total column shows the effect of each factor in the surprise considering the total macroeconomic surprises. The + column considers the effect of positive surprises in the factors. The - column considers the effect of negative surprises in the factors.

*** Significant at $1 \%$.

** Significant at $5 \%$.

* Significant at $10 \%$. 


\section{TABLE 5C}

IMPACT OF SURPRISES AND ANNOUNCEMENTS ON CURVATURE FACTOR $C$ ( $\left.^{*}\right)$

\begin{tabular}{|c|c|c|c|c|c|c|c|c|c|c|c|}
\hline & & \multicolumn{3}{|c|}{ NELSON SIEGEL } & \multicolumn{6}{|c|}{ PRINCIPAL COMPONENTS } \\
\hline & & & All & + & - & All & & + & & - & \\
\hline & & $\begin{array}{l}\text { Constant } \\
\text { Lag }\end{array}$ & $\begin{array}{c}-0.000 \\
(0.006) \\
-0.039 \\
(0.039)\end{array}$ & $\begin{array}{c}0.001 \\
(0.007) \\
-0.038 \\
(0.039)\end{array}$ & $\begin{array}{c}0.001 \\
0.007 \\
-0.038 \\
0.039\end{array}$ & $\begin{array}{c}0.101 \\
(0.121) \\
0.013 \\
(4.074)\end{array}$ & & $\begin{array}{c}0.084 \\
(0.129) \\
0.115 \\
(4.104)\end{array}$ & & $\begin{array}{l}0.084 \\
0.129 \\
0.115 \\
4.104\end{array}$ & \\
\hline \multirow{2}{*}{ 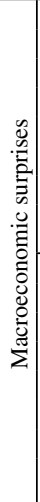 } & 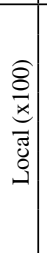 & $\begin{array}{l}\text { Inflation } \\
\text { MPR } \\
\text { Production } \\
\text { Unemployment }\end{array}$ & \begin{tabular}{|l}
3.189 \\
$(16.556)$ \\
$-133.353 * * *$ \\
$(22.801)$ \\
-4.111 \\
$(4.074)$ \\
-15.693 \\
$(15.042)$
\end{tabular} & $\begin{array}{c}-16.840 \\
(15.310) \\
-102.530 \\
(76.596) \\
-1.638 \\
(6.210) \\
-18.573 \\
(21.673)\end{array}$ & $\begin{array}{c}25.394 \\
(30.067) \\
-136.804 * * * \\
(22.748) \\
-7.148 \\
(5.402) \\
-13.993 \\
(20.095)\end{array}$ & $\begin{array}{c}-0.443 \\
(3.446) \\
6.993 \\
(4.889) \\
-0.772 \\
(0.707) \\
-2.669 \\
(2.702)\end{array}$ & & $\begin{array}{c}-2.659 \\
(3.068) \\
20.366 \\
(13.300) \\
-0.684 \\
(1.040) \\
-3.968 \\
(3.773)\end{array}$ & & $\begin{array}{c}2.339 \\
(6.170) \\
5.406 \\
(4.527) \\
-0.858 \\
(0.949) \\
-1.987 \\
(3.652)\end{array}$ & \\
\hline & 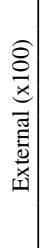 & $\begin{array}{l}\text { Inflation } \\
\text { MPR } \\
\text { Production } \\
\text { Unemployment }\end{array}$ & \begin{tabular}{|c}
-10.829 \\
$(26.313)$ \\
1.244 \\
$(5.878)$ \\
-28.969 \\
$(24.988)$ \\
16.948 \\
$(21.721)$
\end{tabular} & $\begin{array}{l}-17.742 \\
(40.118) \\
-79.328 * * * \\
(19.368) \\
-50.828 \\
(42.578) \\
44.430 \\
(41.462)\end{array}$ & $\begin{array}{c}-4.247 \\
(38.209) \\
2.358 \\
(6.491) \\
-9.187 \\
(30.954) \\
-2.185 \\
(24.707)\end{array}$ & $\begin{array}{c}1.368 \\
(3.890) \\
-1.492 \\
(1.857) \\
-4.721 \\
(5.037) \\
4.437 \\
(3.810)\end{array}$ & & $\begin{array}{c}1.491 \\
(6.260) \\
-30.715 \\
(3.369) \\
-6.634 \\
(8.769) \\
13.119 \\
(5.806)\end{array}$ & $\begin{array}{l}* * * \\
* *\end{array}$ & $\begin{array}{c}0.694 \\
(5.488) \\
-1.170 \\
(1.826) \\
-2.324 \\
(5.722) \\
-1.431 \\
(4.540)\end{array}$ & \\
\hline \multirow[b]{2}{*}{  } &  & $\begin{array}{l}\text { FLAP } \\
\text { Int_2008 } \\
\text { Int_2011 }\end{array}$ & \begin{tabular}{|l}
-60.702 *** \\
$(15.337)$ \\
-2.364 \\
$(10.987)$ \\
$28.149 * * *$ \\
$(2.322)$
\end{tabular} & $\begin{array}{l}-60.772 * * * \\
(15.346) \\
-2.463 \\
(11.018) \\
26.914 * * * \\
(3.271)\end{array}$ & $\begin{array}{l}-60.772 * * * \\
(15.346) \\
-(2.463) \\
(11.018) \\
(26.914) * * * \\
(3.271)\end{array}$ & $\begin{array}{l}-8.601 \\
(3.921) \\
-5.101 \\
(4.973) \\
-3.253 \\
(0.414)\end{array}$ & $\begin{array}{l}* * \\
\\
* * * \\
\end{array}$ & $\begin{array}{l}-8.583 \\
(3.926) \\
-5.083 \\
(4.983) \\
-3.276 \\
(0.517)\end{array}$ & $* *$ & $\begin{array}{r}-8.583 \\
(3.926) \\
-(5.083) \\
(4.983) \\
-3.276 \\
(0.517)\end{array}$ & ** \\
\hline & 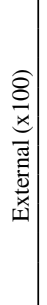 & $\begin{array}{l}\text { QE1 } \\
\text { QE2 } \\
\text { QE3 } \\
\text { Extension } \\
\text { Twist }\end{array}$ & \begin{tabular}{|ll}
-45.812 & $* * *$ \\
$(1.904)$ & \\
33.019 & $* * *$ \\
$(0.632)$ & \\
-13.541 & \\
$(9.037)$ & \\
-0.059 & \\
$(0.631)$ & \\
-9.955 & $* * *$ \\
$(1.121)$ &
\end{tabular} & $\begin{array}{l}-45.659 * * * \\
(2.166) \\
32.924 * * * \\
(0.660) \\
-9.687 \\
(6.151) \\
-0.151 \\
(0.659) \\
-10.016 * * * \\
(1.143)\end{array}$ & $\begin{array}{l}-45.659 * * * \\
(2.166) \\
32.924 \quad * * * \\
(0.660) \\
-9.687 \\
(6.151) \\
-0.151 \\
(0.659) \\
-10.016 * * * \\
(1.143)\end{array}$ & $\begin{array}{c}-4.474 \\
(0.488) \\
5.899 \\
(0.121) \\
-4.045 \\
(1.014) \\
0.899 \\
(0.121) \\
5.900 \\
(0.306)\end{array}$ & $\begin{array}{l}\text { *** } \\
* * * \\
* * * \\
* * * \\
* * *\end{array}$ & $\begin{array}{c}-4.379 \\
(0.497) \\
5.916 \\
(0.129) \\
-3.550 \\
(1.136) \\
0.916 \\
(0.129) \\
5.924 \\
(0.305)\end{array}$ & $\begin{array}{l}* * * \\
* * *\end{array}$ & $\begin{array}{c}-4.379 \\
(0.497) \\
5.916 \\
(0.129) \\
-3.550 \\
(1.136) \\
0.916 \\
(0.129) \\
5.924 \\
(0.305)\end{array}$ & $\begin{array}{l}* * * \\
* * * \\
* * * \\
* * * \\
* * *\end{array}$ \\
\hline & & R2 adj. & 4.43 & 1.20 & 1.20 & 1.12 & & 1.52 & & 1.52 & \\
\hline
\end{tabular}

(*) Results are reported based on the Nelson Siegel model and Principal Components approaches. Coefficients of surprises and local and external advertisements multiplied by 100 . All variables expressed in basis points. The Total column shows the effect of each factor in the surprise considering the total macroeconomic surprises. The + column considers the effect of positive surprises in the factors. The - column considers the effect of negative surprises in the factors.

*** Significant at $1 \%$.

$* * \quad$ Significant at $5 \%$.

* $\quad$ Significant at $10 \%$. 


\section{CONCLUSIONS}

In this paper the structure factors of nominal rates were reported in Chile market during the period 2005-2013 in daily frequency under two mutually exclusive approaches, the approach of Nelson Siegel (NS) and Principal Components Approach (PCA). Both methodologies allow us to represent the information in the yield curve compactly in three factors, denoted as level (L), slope (S), and curvature (C).

This paper attempted to analyze the main factors of the yield curve in Chilean market during the period 2005-2013 at daily frequency. Two different approaches were used to compute the main three factors denoted as the level, slope and curvature of the yield curve; the Nelson-Siegel model and the Principal Component approach. Our results suggests local surprises and announcements (both local and external) have similar effects on the estimated factors under both approaches, whereas is evidenced an asymmetric impact in the case of external surprises.

\section{REFERENCES}

ANG, A. and M. PIAZZESI (2003). "A No-Arbitrage Vector Autoregression of Term Structure Dynamics with Macroeconomic and Latent Variables", Journal of Monetary Economics 50, pp. 745-787.

ALFARO, R., J. BECERRA and A. SAGNER (2011). "Estimación de la Estructura de Tasas Nominales de Chile: Aplicación del Modelo Dinámico Nelson-Siegel”, Economía Chilena 14 (3), pp. 57-74.

BIS (2005). Zero-coupon yield Curves: technical documentation number 25, Bank for International Settlements, Basel.

BLISS, R. (1997), "Movements in the Term Structure of Interest Rates", Economic Review, Federal Reserve Bank of Atlanta 82, pp. 16-33.

CHAUMONT, G. and J. GARCIA-CICCO (2012). "Asset Prices and Monetary Policy in Chile: A heteroskedasticity-based approach", mimeo, Banco Central de Chile.

CORTAZAR, G. and E. SCHWARTZ (1994). "The valuation of commodity-contingent Claims", The Journal of Derivatives 1 (4), pp. 27-39.

DAI, Q. and K. SINGLETON (2000). "Specification analysis of affine term structure models", Journal of Finance 55, pp. 1943-1978.

DIEBOLD, F.X. and C. LI (2006). "Forecasting the Term Structure of Government Bond Yield", Journal of Econometrics 130, pp. 337-364.

GÜRKAYNAK, S, B. SACK and W. SWANSSON (2005). "The Sensitivity of Long-Term Interest Rates to Economic News: Evidence and Implications for Macroeconomic Models", American Economic Review 95 (1), pp. 425-436.

HERRERA, L.O. and I. MAGENDZO (1997). "Expectativas Financieras y la Curva de Tasas Forward de Chile”, Documento de Trabajo $\mathrm{N}^{\circ} 23$, Banco Central de Chile.

HÖRDAHL, P., O. TRISTANI and D. VESTIN (2002). "A joint econometric model of macroeconomic and term structure dynamics". Manuscript, European Central Bank.

LARRAIN, M. (2007). "Sorpresas de política monetaria y la curva de rendimiento en Chile", Economía Chilena 10 (1).

LITTERMAN, R. and J. SCHEINKMAN (1991), “Common Factors Affecting Bond Returns”, Journal of Fixed Income 1, pp. 54-61.

MEYER, J. (2006). "Impacto de las Sorpresas Económicas en el Rendimiento de los Bonos del Banco Central de Chile", NIE Revista de Economía Chilena 9. 
MORALES, M. (2010). "The Real Yield Curve and Macroeconomic Factors in the Chilean Economy", Applied Economics 42 (27), pp. 3533-3545.

NELSON, C. and A. SIEGEL (1987). "Parsimonious Modeling of Yield Curve", The Journal of Business 60 (4), pp. 473-489.

OCHOA, J. (2006). "An Interpretation of an Affine Term Structure Model for Chile”, Estudios de Economía 33 (2), pp. 155-184.

WU, T., (2002). "Monetary policy and the slope factors in empirical term structure estimations", Federal Reserve Bank of San Francisco, Working Paper 02-07. 
